equipment. It may or may not have the qualities of permanence. In any event, while it is upon its present basis, it is freely open to such students and investigators as might wish to work in its vicinity.

\section{Conway MacMillan.}

To the Editor of Science: I have been asked by Dr. A. G. Meyer to express an opinion regarding the establishment of a marine biological laboratory in the tropical Atlantic. As I have never been south of Bermuda, in these waters, I do not know that my ideas on the subject will be of much value. I see by the letters already published that the Tortugas are very generally favored. While for a botanist who is a student of marine algæ only, such a location might be an excellent one, it would hardly be suitable for one who wanted to study any other aspect of botany, for if I am not mistaken the land flora there is exceedingly scanty. A laboratory to be much sought after by botanists must also afford opportunities for the study of land plants, and where tropical vegetation is desired one must go further south than the Tortugas, and in a region where there is more moisture, to find much that is worth while.

Herbert M. Richards.

Barnard College, New York, June 16, 1903.

THE MEDICAL RESEARCH LABORATORY OF COLORADO COLILGE.

To the Editor of Science: It is proposed on the part of Colorado College to establish a pathological and research laboratory. For this purpose a room 23 by 14 feet has been set aside in the new Science Hall, now under erection. This room is to be equipped with chemical hood, water, gas and storage battery facilities. There are two windows in the room having a south exposure. In this laboratory it is planned that the following lines of work be undertaken: (1) Blood examinations, (2) sputum examinations, (3) urine examinations, (4) drinking-water examinations, (5) milk examinations, (6) pathological examinations, (7) stomach contents, (8) feces, (9) X-ray work as an aid to diagnosis, (10) papers and fabrics for mineral poisons.
In addition to these lines of general work special cases, requiring expert knowledge and care, will be undertaken. It is also planned that the director of the laboratory pursue lines of original research such as may be suggested by himself or by members of the committee under which the laboratory is to be conducted. It is hoped that this will grow to be the most important feature of the whole undertaking. Finally the laboratory will offer a limited amount of instruction in the pre-medical course of Colorado College. The amount and character of this instruction will be determined by consultation with the president of the college.

The salary of the director will be $\$ 1,500$ for the first year. It is hoped that thereafter the income of the laboratory will prove sufficient to warrant an increase. It is the desire of the committee to receive applications for the position of director of the laboratory, the appointment being made for one year. The applicant should be a man of scientific spirit and one who is desirous of making his reputation along lines of medical research. It is not essential that he be a graduate of a medical college, but rather that he have had training and experience in some of the best laboratories of this country or Europe. He should not be a person expecting later to enter the practice of medicine.

Applications with full information and testimonials may be sent to

W. F. Slocum.

$$
\begin{aligned}
& \text { Colorado College, } \\
& \text { Colorado Springs, Colo. }
\end{aligned}
$$

\section{ABBREVIATIONS OF NEW MEXICO.}

May I suggest that the name New Mexico should always be abbreviated (if at all) to New Mex. or N. M., never to N. Mex. or N. Mexico? The latter abbreviations have been used a great deal by naturalists, with the result of producing much confusion between New Mexico and North Mexico. Foreigners, especially, are almost sure to take N. Mexico for North Mexico; and I am afraid a good many people, not all foreigners, do not know that there is any difference! (I received the other day a letter from an important scientific 
establishment in New .York, with five cents in stamps on the envelope!) I am aware that in several of my own published papers the objectionable abbreviations occur, but these (and many other queer things) are due to editorial interference.

\section{T. D. A. Cockerell.}

\section{' TABLETTES ZOOLOGIQUES.'}

To the Editor of Science: Will you kindly give me space to inquire if any reader of Science knows of the existence in the United States of a copy of the 'Tablettes Zoologiques'? This journal was published at Poitier, France, by Aimé Schneider. The first volume appeared in 1885, and the third, which I think was the last, in 1892. I have as yet been unable to locate a copy in America, and any information will be very gratefully received.

Wyncote, Pa., June 12, 1903.

\section{SHORTER ARTICLES.}

UNUSUAL ABUNDANCE OF A MYRIAPOD, PARAJULUS PENNSYLVANICUS (BRANDT).*

During the latter part of August and the first of September, 1902, the walks and drives along the university campus were overrun with a myriapod which proved to be Parajulus pennsylvanicus (Brandt). Bright, sunny days, which were likewise cool, were observed to bring a greater number of the species into evidence. Complaints were made by residents along the adjacent avenues of the numbers of these 'worms,' as they were called, which covered the sidewalks and terraces and even entered the residences. Often in passing along the paths running in the campus it was found to be difficult, if not impossible, to avoid crushing numbers at every step. They exhibited no general direction to their movements, and hence a migration from one portion of this locality to another definite locality seems not to be the case. Rather it seems that they were trying to find higher or perhaps dryer ground. When one was taken up

* Read at Columbus meeting, Ohio Academy of Science, November, 1902. in the fingers and then allowed to move in a direction opposite to its original direction, it showed no sign of any attempt at orientation.

A case similar to this one is found every year on Cedar Point, Sandusky, O., where Fontaria indiani Bollman, immediately prior to and during ovipositing, is found in great numbers along the lowlands on the Bay side. But in the case of the one mentioned above as occurring on the campus, of all the females examined, none contained eggs. Hence this is not a true parallelism.

Several cases of extensive migrations of inyriapods are on record. In the Zoologischer Anzeiger for 1900, Verhoeff records a migration of such extent that railroad trains were stopped, owing to the numbers that were crushed under the wheels and thus caused them to slip. The species in this case was Julus terrestris. Verhoeff also calls attention to a description of an extensive migration of a species of Brachyjulus, given in the same journal by an Austrian named Paslavisky, who states that in 1879 , in Austria, this species was excessively numerous in a certain district. Verhoeff regards the cause of such movements as due to over-population, and hence an attempt to obviate the results of the law of Malthus. That this is not the cause in all cases is attested by that of the species of Fontaria that I mentioned as occurring on Cedar Point, which is undoubtedly a purely sexual matter. A third record of such movements is given in Bollman's 'Myriapoda of North America,' in which, on page 75, he mentions the occurrence of Fontaria virginiensis (Drury) in Donaldson, Arkansas, in such numbers as to attract general attention. The adults were found to bear a ratio to the number of young that were observed with them of about one to three hundred. Apparently, this movement is due to a third reason -the migration of the adults with the young. Miss Mauck (American Naturalist, XXXV., 447) gives an account of a migration of Fontaria virginiensis (Drury) but no cause is assigned to the movement.

To conclude, every one of the cases of extensive migrations in myriapoda that have 